L'enseignement supérieur au XXIe siècle. [Електронний ресурс]. - Режим доступу: http://unesdoc.unesco.org/images/ 0011/001163/116345f.pdf 6. Nouveaux espaces pour l'Université. Rapport au Président de la République. - Paris : CNE, 2005. - 129 p. 7. The Bologna Declaration on the European space for higher education: an explanation.19.06.1999 [Електронний ресурс]. Режим доступу: http://www.ec.europa.eu/education/policies/educ/bologna/bologna.pdf. 8. The European Higher Education Area. Joint Declaration of the European Ministers of Education. Convened in Bologna on the 19th of June 1999 [Електронний ресурс]. - Режим доступу: http://www.ntb.ch/ SEFI/bolognadec.html. 10. Towards the European Higher Education Area. Communique of the meeting of the meeting of European Ministers in charge of Higher Education in Prague on May 19th 2001 [Електронний ресурс]. - Режим доступу : http://www.msmt.cz/Summit/Prague\% 20Communique\%20-\%2019-05-2001FINAL.doc.

УДК : 378:378.4-057.875(043.3)

Діана Волківська

\title{
НАУКОВІ ПІДХОДИ ДО РОЗУМІННЯ ПОТЕНЦАЛУ ОСОБИСТОСТІ
}

Волківська Д. А. Наукові підходи до розуміння потенціалу особистості.

У статті розкрито сутність поняття «потенціал особистості» та представлено результати теоретичного аналізу дослідження потенціалу особистості науковцями різних галузей.

Ключові слова: особистість, потенціал, можливості, ресурси, засоби.

Волковская Д. А. Научные подходы к пониманию потенциала личности.

В статье раскрыта сущность понятия «потенциал личности» и представлены результаты теоретического анализа исследования потенциала личности ученими разных отраслей.

Ключевые слова: личность, потенциал, возможности, ресурсы, средства.

Volkivska D. A. Scientific approaches to understanding the potential of the individual.

The article deals with the essence of the concept of «individual capacity» and presents the results of theoretical analysis research potential of the individual scientists from different fields.

Key words: personality, potential, opportunities, resources, tools.

В умовах сучасних соціально-економічних перетворень важливо адекватно реагувати на зміни, для цього потрібно активізувати особистісний потенціал. Кожна людина, без сумнівів, унікальна. Водночас для більшості людей є проблемою достойно презентувати себе світові, довести свою унікальність, розкрити приховані можливості та ресурси.

Тому пошук шляхів розвитку потенціалу особисті $\epsilon$ важливим завдання сьогодення.

Потенціал особистості був предметом вивчення античної філософії (Аристотель, Геродот, Платон, Плутарх) i не втратив актуальності для сучасної науки (Т. Артемьєва, В. Бережна, Д. Берлайн, А. Голованова, Н. Дериглазова, А. Деркач, В. Марков, Н. Миронець, Л. Сохань, І. Утюж). Та проведений теоретичний аналіз надає нам підстави говорити про неоднозначність тлумачення потенціалу особистості дослідниками різних галузей. 
Meта статті - порівняти наукові підходи до розуміння потенціалу особистості.

Категорія «потенціал особистості» є поєднанням двох понять: «потенціал» та «особистість». Не будемо детально аналізувати поняття «особистість», а обмежимося лише узагальненими характеристиками. Переважно, в довідниковій літературі особистість розглядають як стійку систему соціально значущих рис, що характеризують особу як члена того чи іншого суспільства або спільноти; суспільну сутність людини, пов'язану із засвоєнням різноманітного виробничого і духовного досвіду суспільства; сукупність поведінкових дій, суб'єкт-об'єктних взаємозв'язків, особливості особистісного онтогенезу індивіда [3, с. 297].

Термін «потенціал» походить від латинського слова «potentia», сенс якого розкривається словами «сила» та «міць». У словнику С. Ожегова потенціал трактується як «можливість», тобто те, що «існує в прихованому вигляді і може виявитися при відомих умовах», а також визначається як «ступінь потужності в якому-небудь відношенні; сукупність засобів, необхідних для чого-небудь» [6, с. 492].

Звертаючись до енциклопедичних джерел, знаходимо визначення потенціалу як: сукупність усіх наявних засобів, можливостей, продуктивних сил, що можуть бути використані в якій-небудь галузі, ділянці, сфері; приховані здатності, сили для якоїнебудь діяльності, що можуть виявитися за певних умов [8, с. 402]; дещо, що може виявитися i стати реальним; можливість когось або чогось відбутися в майбутньому [9].

Поняття використовується багатьма науками, має спеціальне значення в різних галузях. Наприклад, у фізиці «потенціал»- це величина, що чисельно дорівнює роботі, витраченій на переміщення об'єкту з безмежності в певну точку простору. У географії «потенціал природно-ресурсний»- теоретична кількість природних ресурсів, які без завдання шкоди для природи і людства можуть бути використані в господарських цілях. В економіці, «потенціал»- це наявні в економічного суб'єкта ресурси, їхня оптимальна структура і вміння раціонального використовувати ці ресурси задля досягнення поставленої мети.

Під час розкриття сутності потенціалу особистості ми базувалися насамперед на філософських теоріях. Так, ще у вченні «Метафізика» Аристотель визначає потенцію як здатність речі здійснювати рух або процес. На його думку, існуюче актуально виникає з існуючого потенційно під дією існуючого актуально.

У 80-ті pp. ХХ ст. радянський філософ М. Каган підкореслював, що особистість отримує свою структуру з видової будови людської діяльності і характеризується тому п'ятьма потенціалами»: пізнавальним (сукупність знань і отриманої інформації); аксіологічним (система ціннісних орієнтації); творчим (сукупність умінь i навичок, здібностей до творчості); комунікативним (міра i форма товариськості); художнім (сукупність художніх потреб і способів їх задоволення). Науковці 3. Пушкар, С. Трубич, у свою чергу, серед складових потенціалу особистості виокремлюють: життєвий; освітній; культурний; трудовий; потенціал здоров'я.

У філософських поглядах Н. Миронець поняття потенціалу пов'язується, насамперед, із категоріями можливості й дійсності, які, як модальні характеристики буття, відтворюють не тільки вірогідність, тенденцію становлення, але й сталу реальність. Вітчизняна дослідниця І. Утюж тлумачить потенціал як притаманну матеріально-духовним системам сукупність параметрів, які визначають $\mathrm{i}$ водночас забезпечують наявність у цих системах певних можливостей, здібностей, ресурсів для здійснення ними тих чи інших умов, спрямованих на самозбереження і саморух, а також перетворення характеристик середовища. 
В аспекті нормативного підходу, згідно з поглядами В. Бережної, А. Голованова, Л. Сохань, потенціал - це не лише ступінь потужності в будь-якому відношенні, але й наявність певних можливостей як цільових орієнтирів.

У результаті аналізу можемо констатувати, що філософське бачення потенціалу особистості характеризує його як приховані можливості людини, які можуть бути реалізованими за наявності певних ресурсів. До таких ресурсів дослідники зараховують знання, уміння, здібності, якості, цінності та потреби особистості.

Найгрунтовніші дослідження потенціалу особистості є надбанням психологічної науки. У психологічній літературі досліджуються різні види потенціалу особистості: творчий (Л. Єлагіна, М. Корепанова, П. Кравчук, ЈI. Мещерякова, К. Петров, О. Степанова, Е. Шаміра); інтелектуальний (В. Богдашів, Е. Косьміна); комунікативний (Р. Максимов, С. Самигіна, Л. Столяренко, Е. Сурков,); духовноморальний і емоційно-етичний (Н. Попова, О. Трескін); інноваційний (Д. Ільясов, Є. Пагнаєва, І. Резанович); кар'єрного зросту (А. Деркач, Ю. Сипягіна, О. Фаллер).

Здебільшого, поняття потенційного стосовно особистості співвідноситься 3 їі здібностями і задатками. У гуманістичних теоріях особистості (А. Маслоу, К. Роджерс, Е.Фромм) досліджуване нами поняття тісно пов'язане 3 терміном «актуалізація», який трактується як перехід знань, умінь, навичок, різних форм поведінки, емоційних станів 3 потенційного стану в актуальний, розгортання прихованих ресурсів, потенційних можливостей та здібностей (вродженого потенціалу) пов'язаних з розвитком особистості. К. Роджерс зазначає, що поведінка людини регулюється потребою самоактуалізації, розвитку своїх здібностей, розкриття внутрішнього потенціалу. На думку Е. Фрома, подоланню бездуховності людини сприяє його здатність продуктивно використовувати свої сили, реалізація особистісних потенцій і належних йому можливостей. Засновник третьої віденської школи психології В. Франкл, стверджує, що потенціал розкривається, коли у людини виникає прагнення пізнати сенс життя.

Низка науковців поняття «потенціал» уживає не як науковий конструкт, а метафорично, як синонім терміну «ресурси» або «можливості» (А. Гладишевський, Г. Добров, Н. Крилова, А. Сєлєзньов,). Згідно з російським психологом К. Платоновим потенційні здібності особистості розглядаються як здібності нездійсненої діяльності. Спеціалісти у галузі «паблік рілейшнз» Є. Богданов та В.Зазикін також пов'язують потенціал особистості з розвитком іiі здібностей, особливо складних, які мають відношення до діяльності або таких, що відповідають спрямованості особистості. Як «запас життєвої енергії, задатки, здібності» окреслює досліджуване нами поняття доктор психологічних наук М. Шевандрін. Подібне визначення ми знаходимо і в основоположника наукової соціальної психології Б. Паригіна, який потенціал особистості розглядав як певний рівень іiі психічних можливостей, внутрішньої енергії, спрямованої на її творче самовираження і самоствердження» [7, с. 182].

Проте не всі дослідники пов'язують потенціал 3 природною сутністю особистості. Так, автор теорії соціального научіння, американський персонолог Дж. Роттер розглядав потенціал особистості в контексті поведінкового потенціалу, називаючи його «технікою існування». Подібної думки дотримувався автор бестселерів, присвячених проблемі лідерства Дж. Коттер, наголошуючи на когнітивній сутності потенціалу особистості.

Представниця наукової школи С. Рубінштейна, яка активно розробляла проблему співвідношення актуального і потенційного, Т. Артем'єва, відносить до потенційного цілі, прагнення та ідеали людини, причому перехід від потенційного до 
актуального можливий тільки за умови активності самої особистості. Екс-президент канадської психологічної асоціації Д. Берлайн використовував поняття «потенціал» для опису залежності мотиваційних особливостей. У свою чергу, вітчизняна дослідниця М. Садова, зазначає, що цільові і мотиваційні характеристики потенціалу визначаються таким його складником, як спрямованість особистості.

Серед науковців-психологів є прихильники обох підходів. Як приклад, наведемо думку Президента міжнародної академії акмеологічних наук А. Деркача, який називає складовими потенціалу особистості іiі потенційні (здатності, вроджено зумовлені важливі професійні якості, позитивні спадкові чинники) і поновлювані ресурси (інтелектуальні, психологічні, вольові). Така єдність, уважає автор, сприяє прогресивному особистісному i професійному розвитку [2, с. 87]. До подібного бачення потенціалу схиляється В. Марков, виокремлюючи у ньому два вектори: зовнішній, спрямований на біосферу, соціум; внутрішній, пов'язаний зі спрямованістю особистості. Власне потенціал особистості психолог розглядає як «самокеруючу систему iї відновлюваних внутрішніх ресурсів, які виявляються в діяльності, спрямованій на отримання соціально значущих результатів».

Суттєве значення в дослідженні особистісного потенціалу як інтегральної характеристики особистісної зрілості мали доробки О. Леонтьєва, який розглядав його головним феноменом особистісної зрілості та формою вияву особистісного потенціалу, на його думку, є феномен самодетермінації особистості, тобто здійснення діяльності у відносній свободі від заданих умов цієї діяльності, як зовнішніх так і внутрішніх, під якими розуміються біологічні, частково тілесні передумови, а також потреби, характер та інші стійкі психологічні структури [5, с. 372].

Отже, можемо дійти висновку, що у психології потенціал розглядається як сукупність зовнішніх (активність, потреби, інтелект поведінка, професійний розвиток) та внутрішніх (задатки, здібності, можливості, цілі, мотиви) складників.

Останнім часом поняття «потенціал» активно застосовується в термінологічному апараті педагогіки. Причому йдеться, як правило, про його використання в контексті «потенціалу особистості» (особистісного потенціалу). Розглядаючи роботи, у яких розкриваються різні аспекти реалізації потенціалу особистості, особливості й закономірності його розвитку, з'ясувано, що поняття «потенціал особистості» визначається у педагогічній науці неоднозначно.

Зокрема, російська дослідниця В. Ігнатова розуміє його як «сутнісну видову характеристику людини, яка полягає в сукупності вроджених і набутих здібностей суб'єкта ставитися до навколишньої дійсності, що має об'єктивну спрямованість залежно від потреб особистості й ціннісних орієнтації і реалізується у діяльності» [4, c.79]. Таке розуміння потенціалу пов'язане з актуалізованими в конкретний момент часу можливостями особистості, які здатні виявитися за особливих обставин (чинниках, умовах, засобах та ін).

Вітчизняні науковці (П. Кравчук, О. Чаплигін, Р. Серьожникова) під потенціалом особистості розуміють інтегральну якість, що характеризує певний рівень зрілості іiі сутнісних сил як суб'єкта життєдіяльності та як індивідуальну цінність, що сприяє розширенню іiі можливостей в опануванні своїх суспільних відносин і свого власного саморозвитку.

Дослідниця Н. Дериглазова розмежовує два різновиди потенціалу: формальний потенціал, що означає систему сил, наявність і дія яких визначається на рівні формального розуміння і тлумачення дійсності, але не виникає у реальній, практичній сфері буття; реальний потенціал система сил існуючих і діючих де факто або вже 
маючих можливість існувати і діяти у випадку виникнення ним створення певних додаткових умов [1].

Отже, семантичний аналіз поняття «потенціал» дозволяє припустити, що складником потенціалу в загальному тлумаченні можна вважати можливості, умови, засоби, взаємовідносини між кимось або взаємозв'язки з чимось. Розглядаючи потенціал як сукупність характеристик особистості, можемо стверджувати, що він визначається задатками, здібностями, потребами, ціннісними установками, нахилами, неактуалізованими можливостями, творчими імпульсами, потребами в пізнанні себе i свого оточення. Потенціал особистості також пов'язаний з процесами актуалізації, саморозкриття, самовираження, самоствердження, самореалізації, сходження до самого себе, з прагненням «вийти за свої рамки».

На основі проведеного аналізу можемо зробити висновок, що характеристики потенціалу особистості у філософії, психології, педагогіці певним чином співпадають, оскільки накопичується особистісний потенціал у процесі розвитку людини як індивіда, особистості, суб'єкта діяльності, і визначає як іiі реальні можливості, готовність діяти, так і нереалізовані здатності й ресурси. Перспективи подальших досліджень ми вбачаємо в дослідженні лідерського потенціалу особистості задля пошуку шляхів його розвитку.

\section{Література}

1. Дериглазова Н. В. Зміст поняття «соціальний потенціал особистості» [Електронний ресурс] / Н. В. Дериглазова. - Режим доступу: http://www.nbuv.gov.ua/ portal/Soc_ Gum/Gileya/2010_33/Gileya33/F2_doc.pdf. - Заголовок 3 екрану. 2. Деркач А. А. Акмеологические основы развития профессионала / А. А. Деркач. М. : МПСИ, 2004. - 752 с. 3. Загальна психологія: [підручн. для студентів пед. ін-тов] / за ред. А. В. Петровського. - М. : Просвітництво, 1986. - 308 с. 4. Игнатова В. В. Педагогические факторы духовно-творческого становлення личности в образовательном процессе / В. В. Игнатова. - Красноярск, СибГТУ, 2000. - 272 с. 5. Леонтьев Д. А. Внутренний мир личности // Психология личности в трудах отечественных психологов. - СПб. : Питер, 2000. - С. 372-377. 6. Ожегов С. И. Словарь русского язика / С. И. Ожегов. - М.: Русский язык, 1986. - 796 с. 7. Парыгин Б. Д. Социально-психологический климат коллектива. Пути и методы изучения / Б. Д. Парыгин. - Л., 1981. - 192 с. 8. Словник української мови: в 11 томах. - Том 7, 1976. - 819 с. 9. Oxford dictionaries [Електронний ресурс]. - Режим доступу: http://www. oxforddictionaries. com/definition/english/potential. - Заголовок 3 екрану.

УДК 37.013.74(430)

Віма Гаманюк, Свімлана Амеліна

\section{СТАНДАРТИЗАЦІЯ ІНШОМОВНОЇ ПІДГОТОВКИ В КОНТЕКСТІ ІНТЕГРАЦЇ̈ ДО ЗАГАЛЬНОСВРОПЕЙСЬКОГО ОСВІТНЬОГО ПРОСТОРУ}

Гаманюк В. А., Амеліна С. М. Стандартизація іншомовної підготовки в контексті інтеграції до загальноєвропейського освітнього простору.

У статті досліджується питання впровадження європейських освітніх стандартів в галузі іншомовного навчання у системі вищої немовної освіти в Україні. Аналізуються рамкові програми 3 англійської та німецької мов для професійного спілкування 3 огляду на соціокультурний компонент та орієнтацію на автономне навчання. 